\title{
Biodegradation of dissolved organic carbon in soil extracts and leachates from a temperate forest stand and its relationship to ultraviolet absorbance
}

\author{
XU XingKai ${ }^{*}$, LUO XianBao ${ }^{1,2}$, JIANG SongHua $^{3} \&$ XU ZhongJun ${ }^{3}$ \\ ${ }^{1}$ State Key Laboratory of Atmospheric Boundary Layer Physics and Atmospheric Chemistry, Institute of Atmospheric Physics, Chinese Academy \\ of Sciences, Beijing 100029, China; \\ ${ }^{2}$ Graduate University of Chinese Academy of Sciences, Beijing 100049, China; \\ ${ }^{3}$ Beijing University of Chemical Technology, Beijing 100029, China
}

Received October 10, 2011; accepted November 30, 2011; published online December 30, 2011

\begin{abstract}
The amount and biodegradability of dissolved organic carbon (DOC) in forest floors can contribute to carbon sequestration in soils and the release of $\mathrm{CO}_{2}-\mathrm{C}$ from soil to the atmosphere. There is only limited knowledge about the biodegradation of DOC in soil extracts and leachates due to the limitations inherent in degradation experiments. Differences in the biodegradation of DOC were studied in forest soil extracts using cold and hot water and $4 \mathrm{mmol} / \mathrm{L} \mathrm{CaCl}_{2}$ solution and in soil leachates sampled under different conditions over a wide range of DOC concentrations. From these results, we developed a simple and rapid method for determining the biodegradable organic $\mathrm{C}$ in forest floors. The hot water extracts and $\mathrm{CaCl}_{2}$ extracts after $\mathrm{CH}_{3} \mathrm{Cl}$ fumigation contained higher concentrations of biodegradable organic $\mathrm{C}$ than the cold water extracts and $\mathrm{CaCl}_{2}$ extracts before fumigation, with rapid DOC degradation occurring 24-48 h after incubation with an inoculum, followed by slow DOC degradation till 120-168 h into the incubation. During a 7-d incubation with an inoculum, the variation in DOC degradation in the different soil extracts was consistent with the change in special UV absorbance at $254 \mathrm{~nm}$. Relatively higher levels of biodegradable organic $\mathrm{C}$ were detected in soil leachates from the forest canopy than in forest gaps between April and October $2008(P<0.05)$. Relatively lower concentrations of DOC and biodegradable organic $\mathrm{C}$ were observed in soil leachates from $\mathrm{N}$-fertilized plots during the growing season compared with the control, with the exception of the plot treated with $\mathrm{KNO}_{3}$ at a rate of $45 \mathrm{~kg} \mathrm{~N} \mathrm{ha}^{-1} \mathrm{a}^{-1}$. Around $77.4 \%$ to $96.3 \%$ of the variability in the biodegradable organic $\mathrm{C}$ concentrations in the forest floors could be accounted for by the initial DOC concentration and UV absorbance at $254 \mathrm{~nm}$. Compared with the conventional inoculum incubation method, the method of analyzing UV absorbance at $254 \mathrm{~nm}$ is less time consuming and requires a much smaller sample volume. The results suggest that the regression models obtained using the initial DOC concentration and UV absorbance can provide a rapid, simple and reliable method for determining the biodegradable organic C content, especially in field studies involving relatively large numbers of samples.
\end{abstract}

biodegradable organic carbon, decomposition dynamics, dissolved organic carbon, dissolved organic matter, ultraviolet absorbance, soil extracts and leachates, inoculum incubation

Citation: $\quad \mathrm{Xu} \mathrm{X} \mathrm{K,} \mathrm{Luo} \mathrm{X} \mathrm{B,} \mathrm{Jiang} \mathrm{S} \mathrm{H,} \mathrm{et} \mathrm{al.} \mathrm{Biodegradation} \mathrm{of} \mathrm{dissolved} \mathrm{organic} \mathrm{carbon} \mathrm{in} \mathrm{soil} \mathrm{extracts} \mathrm{and} \mathrm{leachates} \mathrm{from} \mathrm{a} \mathrm{temperate} \mathrm{forest} \mathrm{stand} \mathrm{and} \mathrm{its} \mathrm{rela-}$ tionship to ultraviolet absorbance. Chin Sci Bull, 2012, 57: 912-920, doi: 10.1007/s11434-011-4923-Z

Dissolved organic matter (DOM) is important in the nitrogen and carbon cycles of forest ecosystems [1], and it plays a significant role in many aspects of forest biogeochemistry.

*Corresponding author (email: xingkai_xu@yahoo.com.cn)
Exports of dissolved organic carbon (DOC) from the forest floor to the mineral soil range between 100 and 400 $\mathrm{kg} \mathrm{C} \mathrm{ha} \mathrm{a}^{-1} \mathrm{a}^{-1}$ [2], accounting for between $5 \%$ and $30 \%$ of the above-ground litter input in temperate mature forests [3]. However, the DOC concentrations in deep soil horizons are 
typically low and the $\mathrm{C}$ output from mineral soil in leachate is relatively small (5-66 $\left.\mathrm{kg} \mathrm{C} \mathrm{ha}^{-1} \mathrm{a}^{-1}\right)$ [4-7]. The difference in the fluxes of DOC as it is transported downward in leachate along the soil profile may result in an increase in soil C sequestration, although DOC with high proportions of hydrophilic materials can be decomposed by a wide range of soil bacteria and fungi [8]. In addition to the adsorption and complexation of DOC on the soil surface, soil microorganisms are important determinants of the fate of DOC in the soil. Consequently, the biodegradability and magnitude of the DOC input under forest stands can contribute to heterotrophic respiration in the surface soil and $\mathrm{C}$ sequestration in the mineral soil. To quantify the contribution of DOC to the microbially mediated flux of $\mathrm{CO}_{2}$ from soil to the atmosphere and $\mathrm{C}$ sequestration in mineral soil, the biodegradable or effective DOC pool in forest floors and its responses to different anthropogenic disturbances and environmental changes needs to be measured. Albrechtova et al. [9] reported that the variation in forest floor DOC can be estimated using foliage spectral data, which is a very promising finding with developments in remote sensingbased modelling of forest floor DOC production across different regions. Consequently, the development of rapid methods for monitoring DOC and its degradation in forest floors is very important.

The biodegradation of DOC is defined as the use of organic compounds by soil microorganisms and can be quantified by the disappearance of DOC or by the evolution of $\mathrm{CO}_{2}[8,10]$. The most widely used method to measure DOC biodegradation is batch incubations with measurements of DOC disappearance. Recent studies have developed a standard laboratory-based inoculum incubation for the measurement of DOC degradation [11], but the incubation is laborious, especially for field studies involving relatively large numbers of samples. Furthermore, the use of different microbial inoculums with such an incubation method can cause problems when comparing the results of different studies $[8,12,13]$. The recommended standard method is designed to determine the potentially biodegradable DOC by eliminating possible nutrient limitations and adding a microbial inoculum, but it is not suitable for studying the responses of DOC biodegradation to site specific and temporal variations of other factors controlling microbial activity. Laboratory findings related to the biodegradability of DOC require verification under field conditions [14]. Hence, a rapid, simple and reliable method for determining the biodegradation of DOC sampled in situ under different forest management regimes would be a useful development for studies evaluating the controls on the biodegradability of dissolved organic matter in forest floors.

The chemical and structural characteristics of DOC in terrestrial and aquatic ecosystems are considered to be the most intrinsic factor controlling DOC biodegradability and are closely related to the extent and rate of DOC biodegradation in laboratory incubations. The spectroscopic proper- ties of DOC such as UV absorbance and fluorescence can be used to characterize the dissolved humic substances in the soil and aquatic environment and their responses to changes in anthropogenic and natural conditions $[15,16]$. The UV absorption is a successful predictor of the aromatic $\mathrm{C}$ content of humic acids in soil and the aromaticity of DOC in soil solution and water samples [17,18]. The aromatic and hydrophobic structures of DOC that decrease its biodegradability can also be assessed by analyzing UV absorbance $[10,19,20]$. These results suggest that measuring both the UV absorbance and the DOC concentration would provide a rapid and useful method for determining the amount of biodegradable DOC in soil extracts and leachates sampled in situ under different forest management regimes.

The objectives of this study were to: (i) examine the dynamics of DOC biodegradation in forest soil extracts and compare the results with the UV absorbance of extracts at $254 \mathrm{~nm}$ following a laboratory-based inoculum incubation; and (ii) combine the UV data from forest soil extracts and leachates sampled under different forest management regimes and from forest gaps to develop a calibration model for estimating the biodegradation of DOC sampled in situ from forest ecosystems by considering a wide range of DOC concentrations and different environmental disturbances.

\section{Materials and methods}

\subsection{Preparation of soil extracts and leachates from field experiments}

To study the biodegradation of forest floor DOC and its relationship to UV absorbance, a portion of soils and leachates sampled in 2008 from field experiments under a Korean pine and broadleaf mixed forest in the Changbai Mountains, northeast China, were used. The conditions in this forest stand, and soil properties were reported by $\mathrm{Xu}$ et al. [7,21]. Soil leachates were collected at a soil depth of $15 \mathrm{~cm}$ from different forest management plots (e.g. $\mathrm{C}$ and $\mathrm{N}$ amendments, removal of litter) using purpose built zerotension lysimeters attached to a funnel $(12.5 \mathrm{~cm}$ in diameter).

In July 2006, we established an N-fertilized field experiment with four replicates, which was supplemented with a relatively low dose of added $\mathrm{N}$ in 2007 . Aqueous solutions of $\mathrm{N}$ sources including $\left(\mathrm{NH}_{4}\right)_{2} \mathrm{SO}_{4}, \mathrm{NH}_{4} \mathrm{Cl}$ and $\mathrm{KNO}_{3}$ were sprayed on the ground of four individual plots in equal monthly doses during the tree growing period at rates equivalent to 2.25 and $4.5 \mathrm{~g} \mathrm{~N}$ per $\mathrm{m}^{2}$ each year, and with each application we also applied the equivalent of $5.0 \mathrm{~mm}$ rainfall. Tap water was added to the non-fertilized plot (control) without and with (blank) the removal of litter. The rates of $\mathrm{N}$ application correspond to equal and double the amount of local atmospheric wet $\mathrm{N}$ deposition at present [22]. A glucose addition treatment was also included in the field experiments, with glucose solution sprayed on the 
ground at a rate equivalent to $64 \mathrm{~kg} \mathrm{C} \mathrm{ha}^{-1} \mathrm{a}^{-1}$ in the same manner described for the $\mathrm{N}$-fertilized experiments. This rate of glucose addition corresponds to approximately $25 \%$ of the amount of litter-C delivered to the soil annually, taking into account the amount of $\mathrm{C}$ released by litter decomposition annually and the $\mathrm{CO}_{2}$ evolution involved [23,24]. Due to the higher concentrations of biodegradable dissolved organic $\mathrm{C}$ (BDOC) in soil leachates under the forest canopy than in forest gaps, three different forest gaps (diameter $>10 \mathrm{~m}$ ) and corresponding canopy zones were selected and zerotension lysimeters were installed at a soil depth of $15 \mathrm{~cm}$ in each zone. Four replicate lysimeters were installed in each zone. Forest management regimes and forest gaps can result in differing soil conditions and soil microbial activities, which may affect the biodegradability and concentration of DOC in forest soils and leachates.

The top layer of the forest soils in each plot under different forest management regimes were sampled (in duplicate) during the tree growing period using a soil auger $(3.3 \mathrm{~cm}$ in diameter and $10 \mathrm{~cm}$ in height), with the samples used for laboratory experiments. Sieved fresh soil was frozen at $-20^{\circ} \mathrm{C}$ for no more than 2 months prior to measurement of the biodegradable DOC. To study the differences in DOC biodegradation in forest soil extracts, part of the soil samples from the field experimental plots were initially incubated at $25^{\circ} \mathrm{C}$ for 1 week, and then separately extracted with cold water and hot water (soil: solution, $1: 5$, w/w) at $80^{\circ} \mathrm{C}$, and with a $4 \mathrm{mmol} / \mathrm{L} \mathrm{CaCl}_{2}$ solution $(1: 5$, w/w) both before and after $\mathrm{CH}_{3} \mathrm{Cl}$ fumigation. The low concentration $\mathrm{CaCl}_{2}$ extraction provided a reasonable estimate of the DOC content in soil pore water [25], with a minimal effect on microorganisms due to the low osmotic pressure. All soil extracts were centrifuged at $7000 \times g$ for $10 \mathrm{~min}$, and filtered through a cellulose-acetate membrane filter $(0.45 \mu \mathrm{m}$ pore size $)$. The filtrate was immediately used for measurement of DOC biodegradation. Soil leachate samples from different forest management regimes and forest gaps were filtered through a cellulose-acetate membrane filter $(0.45 \mu \mathrm{m}$ pore size $)$ and stored at $-20^{\circ} \mathrm{C}$ prior to measurement of DOC biodegradation.

\subsection{Measurement of DOC biodegradation and UV absorbance}

To study the DOC biodegradation dynamics in soil extracts, soil samples from the $\mathrm{N}$-fertilized and control plots were extracted with cold and hot water $\left(80^{\circ} \mathrm{C}\right)$, and with a $4 \mathrm{mmol} / \mathrm{L}$ $\mathrm{CaCl}_{2}$ solution before and after $\mathrm{CH}_{3} \mathrm{Cl}$ fumigation. These soil extracts were incubated in $60 \mathrm{~mL}$ tubes at $25^{\circ} \mathrm{C}$ in the dark for $7 \mathrm{~d}$. The tubes were shaken by electrical stirring at $12 \mathrm{~h}$ intervals throughout the incubation period. The extracts were then inoculated with $1 \mathrm{~mL}$ of an inoculation suspension per $100 \mathrm{~mL}$ of extracts. This inoculum was prepared by shaking a mixture of $25 \mathrm{~g}$ of forest topsoil incu- bated at a water capacity of $60 \%$ for two weeks at $20^{\circ} \mathrm{C}$ with $50 \mathrm{~mL}$ of $4 \mathrm{mmol} \mathrm{L}^{-1} \mathrm{CaCl}_{2}$ solution for $30 \mathrm{~min}$, followed by centrifugation at $7000 \times g$ for $10 \mathrm{~min}$. It was then used as the inoculation suspension. This method, which analyzed samples without added nutrients, aimed to compare the differences in the DOC biodegradation and UV absorbance of the soil extracts [11]. Three replicate incubation tubes for each extract were sub-sampled at $0,6,12,18$, $24,48,72,96,120$ and $168 \mathrm{~h}$ after the incubation began to determine the changes in DOC concentrations and special UV absorbance at $254 \mathrm{~nm}$ (SUVA, a measure of aromaticity) of the extracts. The DOC concentrations and UV absorbance at $254 \mathrm{~nm}$ were measured using a TOC/TN-analyzer (Shimadzu TOC- $\mathrm{V}_{\mathrm{CSH}} / \mathrm{TN}$, Kyoto, Japan) and a Unic 2800A spectrophotometer with a 1-cm path-length cell, respectively.

The specific ultraviolet absorbance at $254 \mathrm{~nm}$ was calculated from the UV absorbance at $254 \mathrm{~nm}$ divided by the DOC concentration $\left(\mathrm{mg} \mathrm{C} \mathrm{L}^{-1}\right)$ and the path length of the quartz cell of the spectrophotometer $(\mathrm{cm})$, and is expressed as $\mathrm{L} \mathrm{mg}^{-1} \mathrm{C} \mathrm{cm}^{-1}$. The amount of mineralized $\mathrm{C}$ (defined as the biodegradable dissolved organic $\mathrm{C}, \mathrm{BDOC}$ ) was calculated as the difference in DOC concentrations before and after incubation, providing the DOC mass loss during the incubation. The biodegradation of the inoculum $\mathrm{C}$ was determined from a control sample containing ultra pure water, inoculum and nutrients and subtracted from the other samples. A glucose solution with and without added $\mathrm{N}$ and $\mathrm{P}$ (at a $C: N: P$ ratio of $100: 10: 1)$ was used to test the function of the microbial community.

To quantify the relationships between the BDOC and DOC concentrations of forest soil extracts and leachates and the UV absorbance at $254 \mathrm{~nm}$, three replicates of each soil extract and leachate sample were placed in $60 \mathrm{~mL}$ tubes, inoculated and incubated at $25^{\circ} \mathrm{C}$ in the dark for $5 \mathrm{~d}$, as described above. The DOC concentrations of the samples before and after the incubation were measured using a TOC/ TN-analyzer (Shimadzu TOC- $\mathrm{V}_{\mathrm{CSH}} / \mathrm{TN}$ ). The initial UV absorbance of the samples at $254 \mathrm{~nm}$ was measured using a Unic 2800A spectrophotometer with a 1-cm path-length cell.

\subsection{Calculations and statistical analysis}

The means and standard errors of the DOC and BDOC concentrations and the UV absorbance at $254 \mathrm{~nm}$ for all samples were calculated. Linear regressions of the DOC concentration in the soil extracts or glucose solutions against the incubation time were performed to calculate the rates of DOC biodegradation. Significant differences in the rates of DOC biodegradation between different soil extracts were identified at the $P<0.05$ level using paired-sample $t$-tests. The soil extract and leachate data were used to derive a robust calibration model for estimating the BDOC concentration in forest floors by using the initial DOC concentration and UV absorbance at $254 \mathrm{~nm}$ before incubation. 


\section{Results}

\subsection{Changes in DOC biodegradation in soil extracts and glucose solutions}

Approximately $120 \mathrm{~h}$ after the start of the inoculum incubation, more than $80 \%$ of the glucose- $\mathrm{C}$ with added $\mathrm{N}$ and $\mathrm{P}$ had been mineralized (Figure 1(a)). The mineralization of the inoculum carbon with added $\mathrm{N}$ and $\mathrm{P}$ was negligible in the control samples (ultrapure water, inoculum and nutrients). Thus, approximately $5 \mathrm{~d}$ were required for the inoculum incubation method to determine the BDOC concentration.

The DOC concentrations in the cold water extracts and $\mathrm{CaCl}_{2}$ extracts of forest soils were much lower than those in the hot water extracts and $\mathrm{CaCl}_{2}$ extracts after $\mathrm{CH}_{3} \mathrm{Cl}$
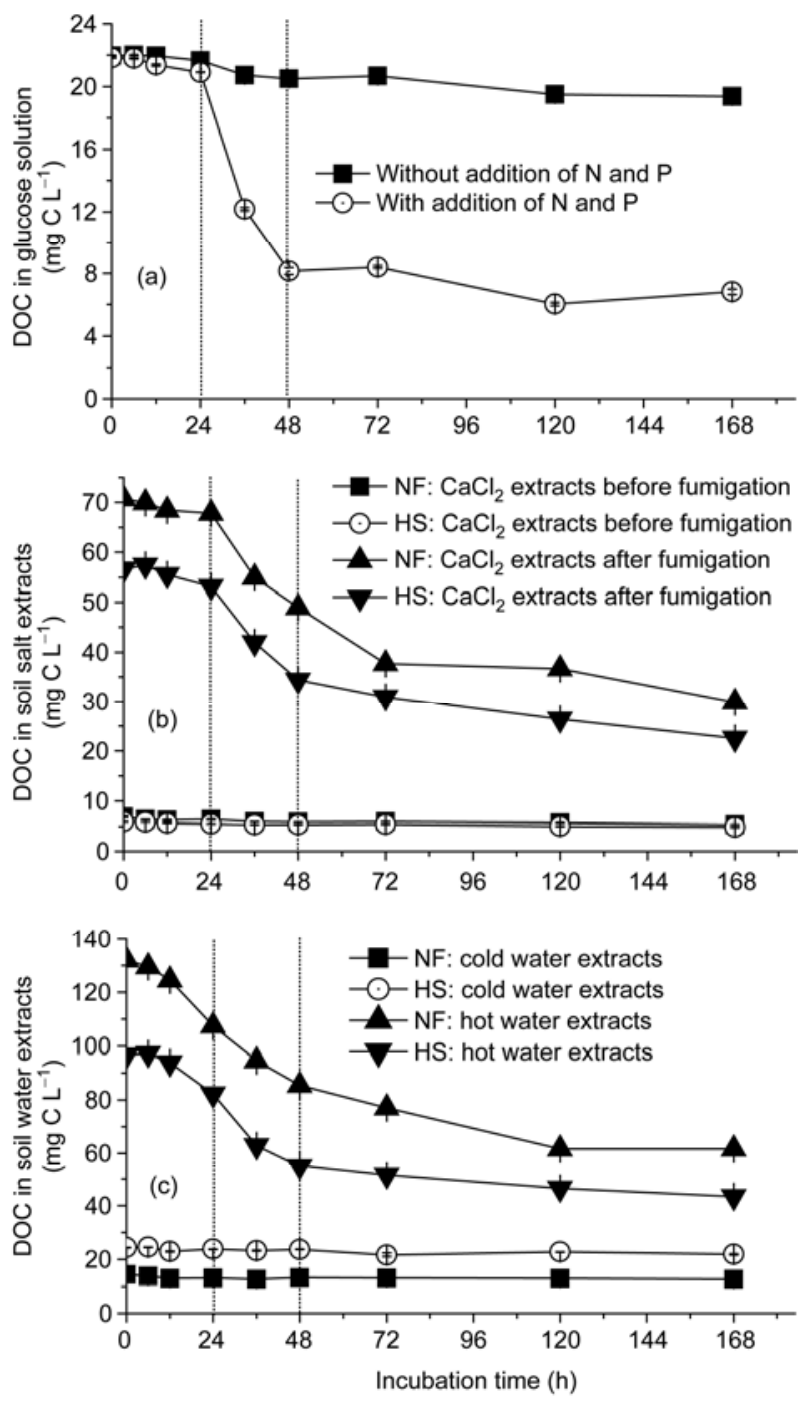

Figure 1 Changes in DOC concentrations in (a) glucose solution with and without added $\mathrm{N}$ and $\mathrm{P}$; (b) $\mathrm{CaCl}_{2}$ soil extracts before and after $\mathrm{CH}_{3} \mathrm{Cl}$ fumigation; and (c) cold and hot water $\left(80^{\circ} \mathrm{C}\right)$ soil extracts during the 168-hour incubation. NF and HS represent mixtures of non-fertilized and experimentally fertilized forest topsoil plots, respectively. Error bars represent the standard error of three replicates. fumigation (Figure 1(b),(c)). The hot water extracts and $\mathrm{CaCl}_{2}$ extracts after $\mathrm{CH}_{3} \mathrm{Cl}$ fumigation also contained higher concentrations of biodegradable DOC, with an initial rapid degradation in the first $24-48 \mathrm{~h}$ of the incubation, followed by a slow degradation rate to 120-168 h (Figure 1(b),(c) and Table 1). In the first $24 \mathrm{~h}$ after the incubation started, the DOC biodegradation rates in the $\mathrm{CaCl}_{2}$ extracts of fumigated soils and in the glucose solution with added $\mathrm{N}$ and $\mathrm{P}$ were negligible, and were significantly lower than the rates in the hot water extracts $(P<0.05)$ (Figure $1(b),(c)$ and Table 1). The initial short-term lag phase for DOC mineralization in the $\mathrm{CaCl}_{2}$ extracts of fumigated soils and glucose solution was probably due to the initial limited number and activity of microorganisms. Overall, compared with the other soil extracts, the hot water extracts of forest soils had higher biodegradable DOC concentrations.

\subsection{Changes in SUVA in soil extracts and glucose solutions}

The cold water extracts and $\mathrm{CaCl}_{2}$ extracts of the soils had initial higher SUVA values compared with the hot water extracts and $\mathrm{CaCl}_{2}$ extracts of fumigated soils, but changes in the SUVA values of the cold water and $\mathrm{CaCl}_{2}$ extracts during the 7-d incubation were negligible (Figure 2(a)-(c)). However, the SUVA values of the hot water extracts and $\mathrm{CaCl}_{2}$ extracts of fumigated soils increased significantly between 24 and $72 \mathrm{~h}$ after the start of incubation and then remained relatively high (Figure 2(b),(c)).

The largest decrease in the biodegradability of DOC in the hot water extracts and $\mathrm{CaCl}_{2}$ extracts of fumigated soils was consistent with the period of increased SUVA at $254 \mathrm{~nm}$ during the 7-d incubation (Figures 1 and 2). These results indicate an enrichment of the aromatic content during the biodegradation of DOC. Surprisingly, the cold water soil extracts had relatively high SUVA values (Figure 2(c)), suggesting that cold water soil extracts may not be good indicators of soil $\mathrm{C}$ bioavailability. The glucose solution without added $\mathrm{N}$ and $\mathrm{P}$ had consistently low SUVA values during the incubation, while the SUVA values of the glucose solution with added $\mathrm{N}$ and $\mathrm{P}$ significantly increased due to degradation after an initial $24 \mathrm{~h}$ delay (Figure 2(a)).

\subsection{Relationships between BDOC, DOC and UV absorbance for soil extracts and leachates}

As shown in Table 1, the DOC and BDOC concentrations in the hot water extracts and $\mathrm{CaCl}_{2}$ extracts after $\mathrm{CH}_{3} \mathrm{Cl}$ fumigation were much larger than those in soil leachates collected at $15 \mathrm{~cm}$ depth. The BDOC concentrations were significantly higher in soil leachates under the forest canopy than those in forest gaps between April and October 2008 $(P<0.05)$, but there were no significant differences in the DOC concentration between the two types of site (Table 1). Somewhat lower DOC and BDOC concentrations were 
Table 1 Slopes $(K)$, coefficients of determination $\left(R^{2}\right)$ and significance levels $(P)$ for linear regressions of the DOC concentration $\left(\mathrm{mg} \mathrm{C} \mathrm{L}^{-1}\right)$ in soil extracts or glucose solutions against the incubation time $(\mathrm{h})^{\mathrm{a})}$

\begin{tabular}{|c|c|c|c|c|c|c|c|c|c|}
\hline \multirow{3}{*}{ Soil extracts or solutions } & \multicolumn{9}{|c|}{ Regression coefficients during different incubation periods } \\
\hline & \multicolumn{3}{|c|}{$0-24 \mathrm{~h}$} & \multicolumn{3}{|c|}{$24-48 \mathrm{~h}$} & \multicolumn{3}{|c|}{$48-168 \mathrm{~h}$} \\
\hline & $K$ & $R^{2}$ & $P$ & $K$ & $R^{2}$ & $P$ & $K$ & $R^{2}$ & $P$ \\
\hline $\begin{array}{l}\text { Glucose solution: with } \\
\text { added } \mathrm{N} \text { and } \mathrm{P}\end{array}$ & $\begin{array}{l}-0.039 \\
(0.004)\end{array}$ & 0.968 & 0.011 & $\begin{array}{l}-0.640 \\
(0.100)\end{array}$ & 0.952 & 0.099 & $\begin{array}{l}-0.025 \\
(0.014)\end{array}$ & 0.403 & 0.224 \\
\hline $\begin{array}{l}\mathrm{NF}: \mathrm{CaCl}_{2} \text { extracts } \\
\text { after fumigation }\end{array}$ & $\begin{array}{l}-0.123 \\
(0.021)\end{array}$ & 0.921 & 0.027 & $\begin{array}{l}-0.724 \\
(0.146)\end{array}$ & 0.887 & 0.038 & $\begin{array}{l}-0.158 \\
(0.013)\end{array}$ & 0.980 & 0.007 \\
\hline $\begin{array}{l}\mathrm{HS}: \mathrm{CaCl}_{2} \text { extracts } \\
\text { after fumigation }\end{array}$ & $\begin{array}{l}-0.143 \\
(0.023)\end{array}$ & 0.926 & 0.025 & $\begin{array}{l}-0.910 \\
(0.062)\end{array}$ & 0.991 & 0.044 & $\begin{array}{r}-0.090 \\
(0.006)\end{array}$ & 0.987 & 0.005 \\
\hline NF: Hot water extracts & $\begin{array}{l}-0.825 \\
(0.175)\end{array}$ & 0.876 & 0.042 & $\begin{array}{l}-0.908 \\
(0.093)\end{array}$ & 0.979 & 0.065 & $\begin{array}{l}-0.329 \\
(0.002)\end{array}$ & 0.999 & 0.004 \\
\hline HS: Hot water extracts & $\begin{array}{r}-0.694 \\
(0.098)\end{array}$ & 0.942 & 0.019 & $\begin{array}{l}-1.185 \\
(0.285)\end{array}$ & 0.890 & 0.150 & $\begin{array}{l}-0.096 \\
(0.004)\end{array}$ & 0.996 & 0.001 \\
\hline
\end{tabular}

a) NF and HS represent mixtures of non-fertilized and experimentally fertilized forest topsoil plots, respectively. The standard error of three replicates is shown in parentheses.
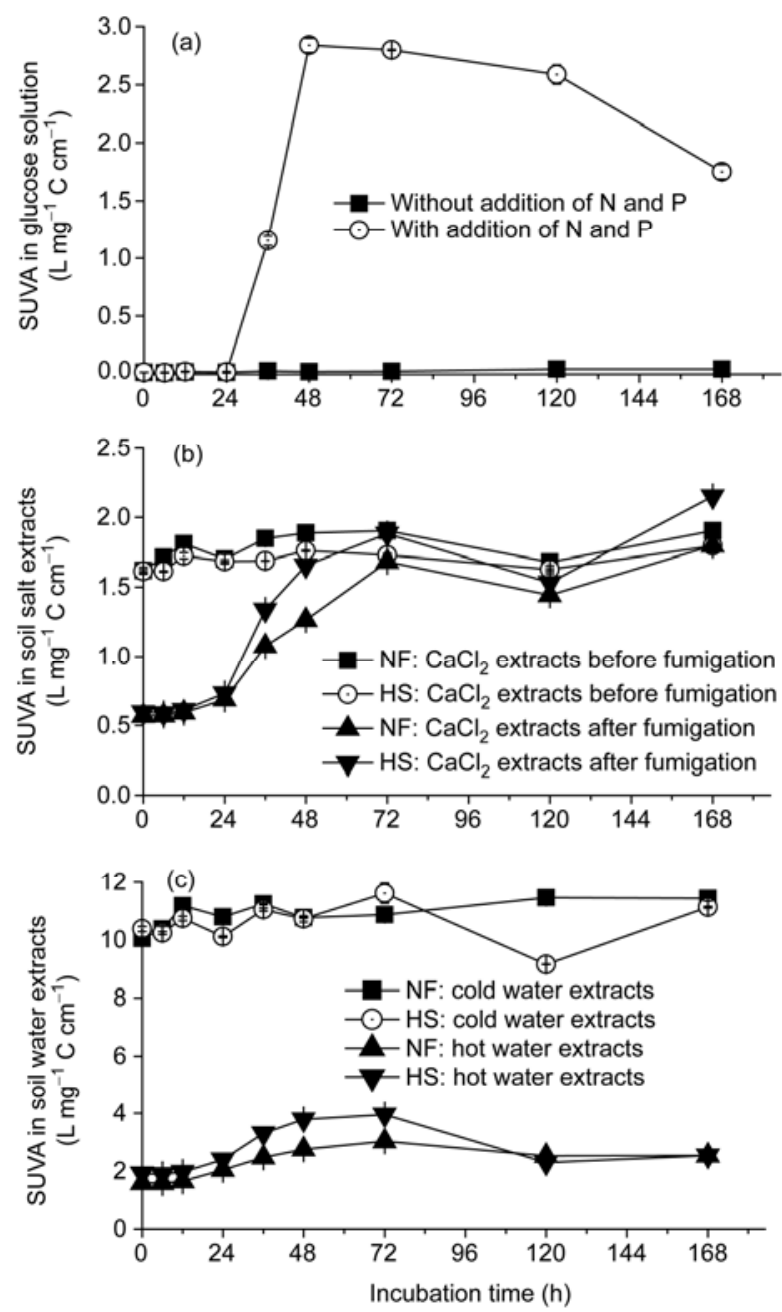

Figure 2 Changes in SUVA values in (a) glucose solution with and without added $\mathrm{N}$ and $\mathrm{P}$; (b) $\mathrm{CaCl}_{2}$ soil extracts before and after $\mathrm{CH}_{3} \mathrm{Cl}$ fumigation; and (c) cold and hot water $\left(80^{\circ} \mathrm{C}\right)$ soil extracts during the 168-h incubation. NF and HS represent mixtures of non-fertilized and experimentally fertilized forest topsoil plots, respectively. Error bars represent the standard error of three replicates.

observed in the soil leachates from the $\mathrm{N}$-fertilized plots during the growing seasons compared with the control, ex- cept for the $\mathrm{KNO}_{3}$-treated plot (45 $\mathrm{kg} \mathrm{N} \mathrm{ha}^{-1} \mathrm{a}^{-1}$ ) and the October samples (Table 1).

For a wide range of DOC concentration, between $62 \%$ and $97 \%$ of the variability in the DOC concentrations of these soil extracts and leachates could be accounted for by the UV absorbance at $254 \mathrm{~nm}$ (Figure 3(a)). The decrease in DOC concentration after incubation was considered to be the BDOC and was linearly correlated with the UV absorbance at $254 \mathrm{~nm}$ of the extracts prior to incubation (Figure 3 (b)). Between $28 \%$ and $78 \%$ of the variability in the BDOC concentrations of these soil extracts and leachates could be accounted for by the UV absorbance (Figure 3(b)). When the initial DOC concentration was incorporated into the UV-based regressions as a covariate, the coefficients of determination increased and the standard errors of the estimates decreased. Consequently, a robust calibration model for estimating BDOC concentrations can be recommended for the forest soil extracts and leachates as follows:

If the initial DOC concentration is more than $50 \mathrm{mg} \mathrm{L}^{-1}$,

$$
\begin{gathered}
y=-(0.674 \pm 0.159)+(0.012 \pm 0.003) a+(0.007 \pm 0.008) b, \\
R^{2}=0.774, n=28, P<0.0001
\end{gathered}
$$

and if the initial DOC concentration is less than $50 \mathrm{mg} \mathrm{L}^{-1}$,

$$
\begin{gathered}
y=-(0.069 \pm 0.031)+(0.037 \pm 0.002) a+(0.038 \pm 0.030) b, \\
R^{2}=0.963, n=33, P<0.0001
\end{gathered}
$$

where $y$ is the BDOC concentration in the forest soil extracts or leachates $\left(\mathrm{mg} \mathrm{C} \mathrm{mL}{ }^{-1}\right)$, and $a$ and $b$ represent the initial DOC concentration ( $\mathrm{mg} \mathrm{C} \mathrm{mL}^{-1}$ ) and UV absorbance at $254 \mathrm{~nm}\left(\mathrm{~cm}^{-1}\right)$ of the soil extracts or leachates, respectively.

\section{Discussion}

Approximately $70 \%$ of the glucose-C was degraded in 2-3 d in this study while Qualls and Haines [26] and Bourbonniere and Creed [27] reported $66 \%$ and $75 \%$ degradation of glucose- $\mathrm{C}$ in the 7 and $5 \mathrm{~d}$ of their studies, respectively. Bowen et al. [28] reported that the DOC mass loss after $70 \mathrm{~d}$ 

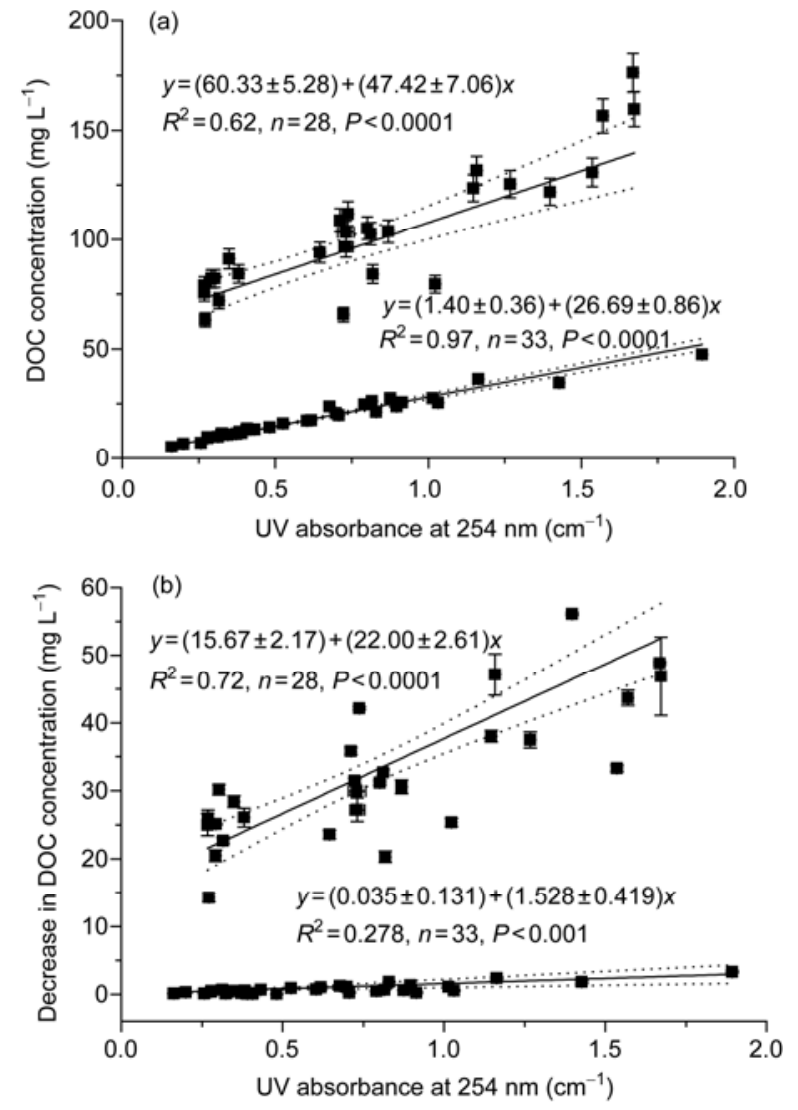

Figure 3 Relationships between (a) the initial DOC concentrations of soil extracts and leachates; and (b) the decrease in DOC concentrations during the 5-d incubation, against the initial UV absorbance at $254 \mathrm{~nm}$ before the incubation. The solid lines represent linear regressions, while the dash lines show the upper and lower $95 \%$ confidence limits.

incubation was equivalent to $96 \%$ of the initial DOC in the glucose solution culture. These different glucose degradation rates can be attributed to different inoculums and incubation conditions. Normally, a glucose solution with added $\mathrm{N}$ and $\mathrm{P}$ is used to assess the ability of a microbial community for DOC degradation. More than $70 \%$ degradation of glucose-C after a short-term incubation indicates good microbial effectiveness of the inoculums in determining the biodegradable organic $\mathrm{C}$ in soil extracts and leachates.

The hot water extracts had relatively higher concentrations of biodegradable organic $\mathrm{C}$ compared with the other soil extracts, with no lag phases at the start of the incubation (Figure 1(c)). This can be explained by the fact that hot water extracts contain substantial amounts of labile and bioavailable C such as carbohydrates [29-31]. Hot water extractable $\mathrm{C}$ is considered to be one of the most sensitive indicators of soil $\mathrm{C}$ availability under different forest sites and management regimes [31-34]. Chloroform fumigation of soil lyses the cells of soil microorganisms and makes their contents partially extractable by $\mathrm{CaCl}_{2}$ solution. The release of soil components of microbial origin due to fumigation [35] can result in a relatively low SUVA in the fu- migated soil $\mathrm{CaCl}_{2}$ extract (Figure 2(b)), and initial DOC biodegradation in these extracts was delayed for $24 \mathrm{~h}$ probably because of the initially limited number and activity of microorganisms. However, within 24-48 h after the start of incubation there were no significant differences in the rates of DOC degradation between the hot water extracts and the $\mathrm{CaCl}_{2}$ extracts of fumigated soils (Table 1). Unfortunately, the microbial mechanisms involving the biodegradation of DOC in soil extracts are unclear at present. The differences in the characteristics of DOC biodegradation (Figure 1 and Table 1) for the different extracts suggest different responses by the microbial communities to different labile organic $\mathrm{C}$ compositions. Due to a lack of information, we were not able to understand the role of bacteria and fungi in DOC biodegradation in soil leachates sampled from different forest stands and seasons.

A significant portion of the $\mathrm{C}$ input from above-ground litter can be translocated as DOC, but the degradability of DOC and its role as a substrate for microbial metabolism is still unclear. Our studies showed that $20 \%-50 \%$ of the DOC in the forest soil extracts during the 5-d incubation was biodegradable (Table 2), which is consistent with previous studies that have reported DOC degradation within the range from $10 \%$ to $88 \%$ measured over periods ranging from a few days to months $[10,36]$. Less than $10 \%$ of the DOC present in forest soil leachates was biodegradable after the 5 day incubation (Table 2), which is in agreement with the results reported by Qualls and Haines [26] and by Jandl and Sletten [37]. However, the proportion of biodegradable DOC in soil solutions was lower than that reported by other researchers $[12,38]$, who identified that $10 \%-30 \%$ of the dissolved organic matter in soil solutions was microbially degradable. The different rates of DOC degradation mainly result from the different sources of DOC, specific site conditions and experimental approaches.

The biodegradable DOC concentration in forest soil leachates is determined by the balance between the production and consumption of BDOC in forest floors. The higher BDOC concentrations in soil leachates under the forest canopy than in forest gaps in the growing season (Table 2) resulted from microbial activities associated with fine root structures. The amount of organic compounds released from roots is greater in the growing season [39], and the rates of root elongation increase with increased temperature [40] and intensity of photosynthesis [41]. Consequently, the difference in the fine root biomass between the forest canopy and forest gaps supports the idea that roots are one of the main sources of BDOC in soil leachates. The inputs of $\mathrm{N}$ into forest floors and the microbial use of $\mathrm{N}$ may lead to a decrease in the biodegradable soil $\mathrm{C}$ concentration, due to increased microbial demand for $\mathrm{C}$ to assimilate the $\mathrm{N}[42,43]$. However, unlike the plots treated with ammonium-N, there were higher DOC and BDOC concentrations in soil leachates from the $\mathrm{KNO}_{3}$-treated plots in the growing seasons than from the control (Table 2). This is consistent with the 
Table 2 Initial DOC concentrations and UV absorbances at $254 \mathrm{~nm}$ for soil extracts and leachates, and the change in DOC concentrations after 5-d incubation ${ }^{\text {a) }}$

\begin{tabular}{|c|c|c|c|c|c|c|c|c|c|}
\hline \multirow{2}{*}{ No. } & \multirow{2}{*}{ Treatments } & \multirow{2}{*}{$\begin{array}{l}\mathrm{UV}_{254} \\
\left(\mathrm{~cm}^{-1}\right)\end{array}$} & \multirow{2}{*}{\multicolumn{2}{|c|}{$\begin{array}{c}\text { Initial DOC } \text { Decrease in DOC } \\
(\mathrm{mg} / \mathrm{L})\end{array}$}} & \multirow{2}{*}{ No. } & \multirow{2}{*}{ Treatments } & \multirow{2}{*}{$\begin{array}{l}\mathrm{UV}_{254} \\
\left(\mathrm{~cm}^{-1}\right)\end{array}$} & Initial DOC & ecrease in DOC \\
\hline & & & & & & & & \multicolumn{2}{|c|}{$(\mathrm{mg} / \mathrm{L})$} \\
\hline \multicolumn{5}{|c|}{$4 \mathrm{mmol} / \mathrm{L} \mathrm{CaCl}_{2}$ soil extracts after $\mathrm{CH}_{3} \mathrm{Cl}$ fumigation } & 30 & 4ForestIn & $0.816(0.001)$ & $26.28(0.13)$ & $0.66(0.05)$ \\
\hline 1 & 9Blank & $0.303(0.001)$ & $82.13(0.51)$ & $30.18(1.50)$ & 31 & 5ForestGap & $0.372(0.002)$ & $11.28(0.01)$ & $0.14(0.02)$ \\
\hline 2 & 9Control & $0.349(0.024)$ & $91.07(0.31)$ & 28.44(1.70) & 32 & 5ForestIn & $0.313(0.001)$ & $9.80(0.03)$ & $0.63(0.00)$ \\
\hline 3 & $9 \mathrm{HKNO}_{3}$ & $0.268(0.010)$ & 78.94(0.94) & $25.02(3.24)$ & 33 & 7ForestGap & $0.915(0.003)$ & $25.58(0.17)$ & $0.24(0.32)$ \\
\hline 4 & $9 \mathrm{HNH}_{4} \mathrm{Cl}$ & $0.271(0.009)$ & $63.20(0.42)$ & $14.23(1.21)$ & 34 & 7ForestGap & $0.383(0.006)$ & $12.07(0.11)$ & $0.52(0.38)$ \\
\hline 5 & $9 \mathrm{H}\left(\mathrm{NH}_{4}\right)_{2} \mathrm{SO}_{4}$ & $0.292(0.004)$ & $81.90(0.22)$ & $20.47(1.71)$ & 35 & 7ForestIn & $0.830(0.004)$ & $21.17(0.13)$ & $1.82(0.12)$ \\
\hline 6 & $9 \mathrm{LKNO}_{3}$ & $0.316(0.004)$ & 71.97(1.17) & $22.70(0.90)$ & 36 & 7ForestIn & $0.896(0.002)$ & $23.80(0.26)$ & $1.30(0.12)$ \\
\hline 7 & $9 \mathrm{LNH}_{4} \mathrm{Cl}$ & $0.269(0.013)$ & $75.57(1.65)$ & $25.99(2.41)$ & 37 & 10ForestGap & $0.482(0.001)$ & $14.23(0.17)$ & $0.01(0.05)$ \\
\hline 8 & $9 \mathrm{~L}\left(\mathrm{NH}_{4}\right)_{2} \mathrm{SO}_{4}$ & $0.293(0.011)$ & $82.12(0.88)$ & $25.10(0.24)$ & 38 & 10ForestIn & $0.698(0.005)$ & $20.61(0.10)$ & $1.05(0.39)$ \\
\hline 9 & 9Glucose & $0.381(0.019)$ & $84.27(1.09)$ & $26.10(2.74)$ & 39 & 4Blank & $0.345(0.000)$ & $10.88(0.25)$ & $0.47(0.11)$ \\
\hline 10 & 10Blank & $0.712(0.010)$ & $108.76(0.06)$ & $35.84(1.06)$ & 40 & 4Control & $0.433(0.002)$ & $13.36(0.09)$ & $0.64(0.02)$ \\
\hline 11 & 10Control & $0.869(0.017)$ & $103.76(0.98)$ & $30.59(2.05)$ & 41 & $4 \mathrm{HKNO}_{3}$ & $0.408(0.002)$ & 13.62(0.05) & $0.17(0.51)$ \\
\hline 12 & $10 \mathrm{HKNO}_{3}$ & $0.801(0.001)$ & $105.19(0.55)$ & $31.20(0.62)$ & 42 & $4 \mathrm{HNH}_{4} \mathrm{Cl}$ & $0.279(0.000)$ & $9.29(0.02)$ & $0.33(0.10)$ \\
\hline 13 & $10 \mathrm{HNH}_{4} \mathrm{Cl}$ & $0.819(0.012)$ & $84.13(0.27)$ & $20.32(1.64)$ & 43 & $4 \mathrm{H}\left(\mathrm{NH}_{4}\right)_{2} \mathrm{SO}_{4}$ & $0.200(0.001)$ & $6.65(0.02)$ & $0.25(0.15)$ \\
\hline 14 & $10 \mathrm{H}\left(\mathrm{NH}_{4}\right)_{2} \mathrm{SO}_{4}$ & 0.731(0.046) & $96.67(1.83)$ & $27.22(3.46)$ & 44 & 5-6Blank & $0.525(0.001)$ & $15.87(0.11)$ & $0.86(0.37)$ \\
\hline 15 & $10 \mathrm{LKNO}_{3}$ & $0.730(0.052)$ & $103.22(0.30)$ & $29.98(0.12)$ & 45 & 5-6Control & $0.618(0.002)$ & $17.40(0.05)$ & $0.98(0.56)$ \\
\hline 16 & $10 \mathrm{LNH}_{4} \mathrm{Cl}$ & $0.646(0.015)$ & $94.01(0.37)$ & 23.61(1.21) & 46 & $5-6 \mathrm{HKNO}_{3}$ & $1.014(0.002)$ & $27.58(0.30)$ & $1.09(0.28)$ \\
\hline 17 & $10 \mathrm{~L}\left(\mathrm{NH}_{4}\right)_{2} \mathrm{SO}_{4}$ & $0.812(0.013)$ & $102.73(0.67)$ & $32.72(0.86)$ & 47 & $5-6 \mathrm{HNH}_{4} \mathrm{Cl}$ & $0.280(0.002)$ & $9.73(0.15)$ & $0.46(0.08)$ \\
\hline 18 & 10Glucose & $0.738(0.025)$ & $111.82(0.12)$ & $42.09(0.49)$ & 48 & $5-6 \mathrm{H}\left(\mathrm{NH}_{4}\right)_{2} \mathrm{SO}_{4}$ & $0.707(0.001)$ & $19.66(0.09)$ & $0.24(0.20)$ \\
\hline \multicolumn{5}{|c|}{ Soil hot water extracts at $80^{\circ} \mathrm{C}$} & 49 & $5-6 \mathrm{LKNO}_{3}$ & $0.407(0.000)$ & $13.04(0.10)$ & $0.04(0.16)$ \\
\hline 19 & 8Blank & $1.268(0.006)$ & $125.35(0.45)$ & $37.46(2.36)$ & 50 & $5-6 \mathrm{~L}\left(\mathrm{NH}_{4}\right)_{2} \mathrm{SO}_{4}$ & $0.324(0.004)$ & $11.18(0.21)$ & $0.12(0.08)$ \\
\hline 20 & 8Control & $1.147(0.001)$ & $123.60(0.00)$ & $38.03(1.69)$ & 51 & 7-8Blank & $0.604(0.002)$ & $17.21(0.32)$ & $0.70(0.35)$ \\
\hline 21 & $8 \mathrm{HKNO}_{3}$ & $1.570(0.018)$ & $156.50(0.30)$ & $43.65(2.25)$ & 52 & 7-8Control & $1.427(0.001)$ & $34.63(0.31)$ & $1.78(0.45)$ \\
\hline 22 & $8 \mathrm{HNH}_{4} \mathrm{Cl}$ & $1.023(0.016)$ & $79.58(0.71)$ & $25.36(1.21)$ & 53 & $7-8 \mathrm{HKNO}_{3}$ & $1.894(0.002)$ & 47.47(0.09) & $3.30(0.35)$ \\
\hline 23 & 8Glucose & $1.536(0.015)$ & $130.80(0.90)$ & $33.30(0.93)$ & 54 & $7-8 \mathrm{HNH}_{4} \mathrm{Cl}$ & $1.032(0.002)$ & $25.42(0.27)$ & $0.54(0.21)$ \\
\hline 24 & 9Blank & $1.668(0.010)$ & $176.20(0.10)$ & $48.85(0.45)$ & 55 & $7-8 \mathrm{H}\left(\mathrm{NH}_{4}\right)_{2} \mathrm{SO}_{4}$ & $0.391(0.002)$ & 11.52(0.09) & $0.01(0.03)$ \\
\hline 25 & 9Control & $1.158(0.005)$ & $131.65(0.15)$ & $47.10(6.12)$ & 56 & $7-8 \mathrm{LKNO}_{3}$ & $0.257(0.002)$ & 7.08(0.02) & $0.11(0.03)$ \\
\hline 26 & $9 \mathrm{HKNO}_{3}$ & $1.673(0.000)$ & $159.60(0.90)$ & 46.88(11.64) & 57 & $7-8 \mathrm{LNH}_{4} \mathrm{Cl}$ & $0.162(0.001)$ & $5.11(0.02)$ & $0.09(0.01)$ \\
\hline 27 & $9 \mathrm{HNH}_{4} \mathrm{Cl}$ & $0.723(0.014)$ & $65.58(0.26)$ & $31.46(0.81)$ & 58 & 10Control & $0.791(0.002)$ & $24.62(0.25)$ & $0.48(0.15)$ \\
\hline 28 & 9Glucose & $1.398(0.006)$ & $121.90(0.40)$ & $56.10(0.33)$ & 59 & $10 \mathrm{HKNO}_{3}$ & $1.163(0.005)$ & $36.16(0.26)$ & $2.38(0.34)$ \\
\hline \multicolumn{5}{|c|}{ Soil leachates collected using zero-tension lysimeters } & 60 & $10 \mathrm{HNH}_{4} \mathrm{Cl}$ & $0.876(0.000)$ & $27.58(0.06)$ & $0.61(0.09)$ \\
\hline 29 & 4ForestGap & $0.327(0.002)$ & $11.34(0.11)$ & $0.20(0.01)$ & 61 & $10 \mathrm{H}\left(\mathrm{NH}_{4}\right)_{2} \mathrm{SO}_{4}$ & $0.678(0.001)$ & $23.68(0.12)$ & $1.21(0.08)$ \\
\hline
\end{tabular}

a) The initial numbers for each treatment indicate the sampling months for soil samples and soil solution mixtures; $\mathrm{H}$ and $\mathrm{L}$ represent 45 and $22.5 \mathrm{~kg} \mathrm{~N}$ ha $^{-1}$ $\mathrm{a}^{-1}$ for N-fertilized plots, respectively; ForestGap and ForestIn represent plots in forest gaps and beneath the forest canopy, respectively.

results reported by Liu and Greaver [44], who found that the soil DOC concentration was significantly increased (by $116 \%$ ) by the addition of $\mathrm{NO}_{3}^{-}$. Similarly, Evans et al. [45] found that the addition of $\mathrm{NaNO}_{3}$ consistently increased the soil DOC concentration while the addition of $\mathrm{NH}_{4}^{+}$salts tended to decrease DOC at their 12 study sites. They hypothesized that the change in soil DOC was probably associated with the effects of different $\mathrm{N}$ forms on soil acidification. Consequently, the change in soil properties such as acidity and the responses of fine root growth and litter de- composition to $\mathrm{N}$ amendments [12,46-48] could have a significant impact on the DOC and BDOC concentrations in soil leachates. Further research is required to explain how these factors can affect the concentration and biodegradation of DOC in soil leachates sampled under $\mathrm{N}$-fertilized forest floors.

The characteristics of DOC with aromatic and hydrophobic structures can be assessed by the UV absorbance [10, 18-20]. For a wide range of DOC concentrations, the different UV absorbance at $254 \mathrm{~nm}$ could explain $62 \%$ and 
97\% of the variation in DOC concentrations in soil extracts and leachates, respectively (Figure 3(a)). This result supports our hypothesis that a UV-based method can rapidly determine the amount of DOC in soil extracts and leachate sampled under forest floors, especially for field studies involving relatively large numbers of samples. The soil hot water extracts and $\mathrm{CaCl}_{2}$ extracts of fumigated soils had high levels of DOC mineralization, and differed markedly from the other soil extracts due to their greater initial specific UV absorbance values (Figures 1 and 2). In several studies, the extent of DOM degradation was inversely related to the UV absorbance and the size of the hydrophobic fraction [26,37, $49,50]$. It seems reasonable to assume that the differences in the biodegradation of DOC in soil extracts and leachates were caused by differences in the DOC composition. The strong correlation between the UV absorbance at $254 \mathrm{~nm}$ for the soil extracts and leachates, and the biodegradation of DOC supports the findings of Kalbitz et al. [10] and confirms the suitability of a spectroscopic method such as UV absorbance to rapidly estimate the biodegradability of DOC in forest floors.

In summary, the hot water soil extracts had relatively high biodegradable organic $\mathrm{C}$ contents and can be considered a good indicator of soil $\mathrm{C}$ bioavailability. The UV absorbance at $254 \mathrm{~nm}$ in combination with the initial DOC concentration could provide a rapid, simple and reliable method for determining the biodegradable organic $\mathrm{C}$ in forest soil extracts and leachates. As site-specific factors such as vegetation, land use and the seasonality of meteorological parameters can affect DOM composition and its biodegradability, a wide range of DOM sources sampled from different sites should be considered before any such UV-based method for determining the biodegradable organic $\mathrm{C}$ is used for all soil extracts and leachates.

This work was supported by the National Basic Research Program of China (2010CB950602) and the National Natural Science Foundation of China (40875085, 41021004 and 41175133).

1 McDowell W H. Dissolved organic matter in soils - Future directions and unanswered questions. Geoderma, 2003, 113: 179-186

2 Michalzik B, Kalbitz K, Park J H, et al. Fluxes and concentrations of dissolved organic carbon and nitrogen-A synthesis for temperate forests. Biogeochemistry, 2001, 52: 173-205

3 Vogt K A, Grier C C, Vogt D J. Production, turnover, and nutrient dynamics of aboveground and belowground detritus of world forests. In: Macfadyen A, Ford E D, eds. Adv Ecol Res, 1986, 15: 303-377

4 Guggenberger G, Zech W. Dissolved organic carbon control in acid forest soils of the Fichtelgebirge (FRG) as revealed by distribution patterns and structural composition analysis. Geoderma, 1993, 59: 109-129

5 Michalzik B, Matzner E. Dynamics of dissolved organic nitrogen and carbon in a Central European Norway spruce ecosystem. Eur J Soil Sci, 1999, 50: 579-590

6 Solinger S, Kalbitz K, Matzner E. Controls on the dynamics of dissolved organic carbon and nitrogen in a Central European deciduous forest. Biogeochemistry, 2001, 55: 327-349

$7 \mathrm{Xu}$ X K, Han L, Luo X B, et al. Effects of nitrogen addition on dis- solved $\mathrm{N}_{2} \mathrm{O}$ and $\mathrm{CO}_{2}$, dissolved organic matter, and inorganic nitrogen in soil solution under a temperate old-growth forest. Geoderma, 2009, 151: 370-377

8 Marschner B, Kalbitz K. Controls of bioavailability and biodegradability of dissolved organic matter in soils. Geoderma, 2003, 113: 211235

9 Albrechtova J, Seidl Z, Aitkenhead-Peterson J, et al. Spectral analysis of coniferous foliage and possible links to soil chemistry: Are spectral chlorophyll indices related to forest floor dissolved organic $\mathrm{C}$ and N? Sci Total Environ, 2008, 404: 424-432

10 Kalbitz K, Schmerwitz J, Schwesig D, et al. Biodegradation of soil-derived dissolved organic matter as related to its properties. Geoderma, 2003, 113: 273-291

11 McDowell W H, Zsolnay A, Aitkenhead-Peterson J A, et al. A comparison of methods to determine the biodegradable dissolved organic carbon from different terrestrial sources. Soil Biol Biochem, 2006, 38: 1933-1942

12 Yano Y, McDowell W H, Aber J D. Biodegradable dissolved organic carbon in forest soil solution and effects of chronic nitrogen deposition. Soil Biol Biochem, 2000, 32: 1743-1751

13 Trulleyová Š, Rulík M. Determination of biodegradable dissolved organic carbon in waters: Comparison of batcg methods. Sci Total Environ, 2004, 332: 253-260

14 Kalbitz K, Solinger S, Park J H, et al. Controls on the dynamics of dissolved organic matter in soils: A review. Soil Sci, 2000, 165: 277-304

15 Kalbitz K, Geyer W, Geyer S. Spectroscopic properties of dissolved humic substances-A reflection of land use history in a fen area. Biogeochemistry, 1999, 47: 219-238

16 Xie X N, Wang S J, Zhou Y C, et al. Three-dimensional fluorescence spectral characteristics of dissolved organic carbon in cave drip waters and their responses to environment changes: Four cave systems as an example in Guizhou Province, China. Chin Sci Bull, 2008, 53: 884-889

17 Traina S J, Novak J, Smeck N E. An ultraviolet absorbance method of estimation of the percent aromatic carbon of humic acids. J Environ Qual, 1990, 19: 151-153

18 McKnight D M, Harnish R, Wershaw R L, et al. Chemical characteristics of particulate, colloidal, and dissolved organic material in Loch Vale Watershed, Rocky Mountain National Park. Biogeochemistry, 1997, 36: 99-124

19 Chin Y P, Aiken G, Oloughlin E. Molecular-weight, polydispersity, and spectroscopic properties of aquatic humic substances. Environ Sci Technol, 1994, 28: 1853-1858

20 Dilling J, Kaiser K. Estimation of the hydrophobic fraction of dissolved organic matter in water samples using UV photometry. Water Res, 2002, 36: 5037-5044

21 Xu X K, Han L, Wang Y S, et al. Influence of vegetation types and soil properties on microbial biomass carbon and metabolic quotients in temperate volcanic and tropical forest soils. Soil Sci Plant Nutr, 2007, 53: 430-440

22 Xu X K, Han L, Luo X B. Effects of stimulated N deposition on soil net $\mathrm{N}$ mineralization under a temperate Korean pine and broadleaf mixed forest (in Chinese). Clim Environ Res, 2012 (in press)

23 Liu Y, Han S J, Lin L. Dynamic changes in soil nutrients of four types of forests in Changbai Mountains during litter decomposition (in Chinese). J Northeast For Univ, 2009, 37: 28-30

24 Han L. Effects of $\mathrm{C}$ and $\mathrm{N}$ disturbances on $\mathrm{C}$ and $\mathrm{N}$ processes in temperate forest soil. Dissertation for Doctoral Degree. Beijing: Institute of Atmospheric Physics, Chinese Academy of Sciences, 2009

25 Fest E P M J, Temminghoff E J M, Comans R N J, et al. Partitioning of organic matter and heavy metals in a sandy soil: Effects of extracting solution, solid to liquid ratio and $\mathrm{pH}$. Geoderma, 2008, 146: 66-74

26 Qualls R G, Haines B L. Biodegradability of dissolved organic matter in forest throughfall, soil solution and stream water. Soil Sci Soc Am J, 1992, 56: 578-586

27 Bourbonniere R A, Creed I F. Biodegradability of dissolved organic matter extracted from a chronosequence of forest-floor materials. $\mathbf{J}$ 
Plant Nutr Soil Sci, 2006, 169: 101-107

28 Bowen S R, Gregorich E G, Hopkins D W. Biochemical properties and biodegradation of dissolved organic matter from soils. Biol Fertil Soils, 2009, 45: 733-742

29 Ghani A, Dexter M, Perrott K W. Hot-water extractable carbon in soils: A sensitive measurement for determining impacts of fertilization, grazing and cultivation. Soil Biol Biochem, 2003, 35: 1231-1243

30 Landgraf D, Leinweber P, Makeschin F. Cold and hot water-extractable organic matter as indicators of litter decomposition in forest soils. J Plant Nutr Soil Sci, 2006, 169: 76-82

31 Balaria A, Johnson C E, Xu Z H. Molecular-scale characterization of hot-water-extractable organic matter in organic horizons of a forest soil. Soil Sci Soc Am J, 2009, 73: 812-821

32 Chodak M, Khanna P, Beese F. Hot water extractable $\mathrm{C}$ and $\mathrm{N}$ in relation to microbiological properties of soils under beech forests. Biol Fertil Soils, 2003, 39: 123-130

33 Wang Q K, Wang S L. Soil organic matter under different forest types in sourthern China. Geoderma, 2007, 142: 349-356

34 Zhang J, Wang S L, Feng Z W, et al. Carbon mineralization of soils from native evergreen broadleaf forest and three plantations in mid-subtropic China. Commun Soil Sci Plant Anal, 2009, 40: 1964-1982

35 Xu X, Zhang T, Liu Z. Calibration model of microbial biomass carbon and nitrogen concentrations in soils using ultraviolet absorbance and soil organic matter. Eur J Soil Sci, 2008, 59: 630-639

36 Boyer J N, Groffman P M. Bioavailability of water extractable organic carbon fractions in forest and agricultural soil profiles. Soil Biol Biochem, 1996, 28: 783-790

37 Jandl R, Sletten R S. Mineralization of forest soil carbon: Interactions with metals. J Plant Nutr Soil Sci, 1999, 162: 623-629

38 Sachse A, Babenzien D, Ginzel G, et al. Characterization of dissolved organic carbon (DOC) in a dystrophic lake and an adjacent fen. Biogeochemistry, 2001, 54: 279-296

39 Paul E A, Clark F E. Occurrence and distribution of soil organisms.
In: Paul E A, Clark F E, eds. Soil Microbiology and Biochemistry. San Diego: Academic Press, 1996. 109-128

40 Tryon P R, Chapin F S. Temperature control over root growth and root biomass in taiga forest trees. Can J For Res, 1983, 13: 827-833

41 Missson L, Gershenson A, Tang J W, et al. Influecnes of canopy photosynthesis and summer rain pulses on root dynamics and soil respiration in a young ponderosa pine forest. Tree Physiol, 2006, 26 : 833-844

42 Aber J D, Nadelhoer K J, Steudler P, et al. Nitrogen saturation in northern forest ecosystems. BioScience, 1989, 39: 378-386

43 Aber J D, Magill A, Boone R, et al. Plant and soil responses to chronic nitrogen additions at the Harvard Forest, Massachusetts. Ecol Appl, 1993, 3: 156-166

44 Liu L L, Greaver T L. A global perspective on belowground carbon dynamics under nitrogen enrichment. Ecol Lett, 2010, 13: 819-828

45 Evans C, Goodale C, Caporn S, et al. Does elevated nitrogen deposition or ecosystem recovery from acidification drive increased dissolved organic carbon loss from upland soil? A review of evidence from field nitrogen addition experiments. Biogeochemistry, 2008, 91: 13-35

46 Nadelhoffer K J. The potential effects of nitrogen deposition on fine-root production in forest ecosystems. New Phytol, 2000, 14: 131-139

47 Smemo K A, Zak D R, Pregitzer K S. Chronic experimental $\mathrm{NO}_{3}^{-}$ deposition reduces the retention of leaf litter DOC in a northern hardwood forest soil. Soil Biol Biochem, 2006, 38: 1340-1347

$48 \mathrm{Xu} \mathrm{X} \mathrm{K,} \mathrm{Han} \mathrm{L,} \mathrm{Luo} \mathrm{X} \mathrm{B,} \mathrm{et} \mathrm{al.} \mathrm{Synergistic} \mathrm{effects} \mathrm{of} \mathrm{nitrogen}$ amendments and ethylene on atmospheric methane uptake under a temperate old-growth forest. Adv Atmos Sci, 2011, 4: 843-854

49 Gilbert E. Biodegradability of ozonation products as a function of COD and DOC elimination by the example of humic acids. Water Res, 1988, 22: 123-126

50 Jandl R, Sollins P. Water extractable soil carbon in relation to the belowground carbon cycle. Biol Fertil Soils, 1997, 25: 196-201

Open Access This article is distributed under the terms of the Creative Commons Attribution License which permits any use, distribution, and reproduction in any medium, provided the original author(s) and source are credited. 